\title{
The Schizophrenia in The Main Character of A Beautiful Mind Movie Directed by Ron Howard
}

\author{
Sri Arfani ${ }^{1}$, Safitri ${ }^{2}$ \\ ${ }^{1,2}$ ABA BSI Jakarta \\ Jl. Salemba Tengah No. 45. Jakarta Pusat \\ Email: ${ }^{1}$ sri.saf@bsi.ac.id, ${ }^{2}$ safitri@bsi.ac.id
}

\begin{abstract}
In literary works character and characterization are important elements because they built the story. Character is a person represented in a movie, story or other narrative work. In the movie, the character can be used as a field to be analyzed, one of which is psychology. Psychology discussed in this paper in term of psychological illness that is schizophrenia. The objective of this analyze is to know the schizophrenia that experienced by main character, John Nash that taken from A Beautiful Mind movie. The Analyses are kinds of schizophrenia, the struggles of Nash, and the moral value that we can get from this movie. There are 3 Kinds of schizophrenia that showed in this movie. First, is about paranoid schizophrenia. The symptoms of paranoid are hallucinations and delusions. Second is about disorganized schizophrenia. There are symptoms that experienced by disorganized schizophrenia: disorganized speech and disorganized behavior. Third is about undifferentiated schizophrenia. The symptoms are seeming lack of interest in the world: social withdrawal. As the result of schizophrenia that experienced by John Nash, he experience of better alteration. At the end, Nash win the Nobel Prize. Although his hallucination friends never gone, but he never think about it.
\end{abstract}

Key Words : Character, Psychological Disorder, Schizophrenia, A Beautiful Mind Movie

\section{INTRODUCTION}

\section{Background}

Literature is a term used to describe written and sometimes spoken material. Derived from the Latin Litteratura meaning "writing formed with letters," literature most commonly refers to works of the creative imagination, including poetry, drama, fiction, and nonfiction. Why do we read literature? Literature represents the culture and tradition of a language or a people. But, literature is more than just a historical or cultural artifact, but can serve as an introduction to a new world of experience. In this case, the writer chooses to discuss the movie. In a movie there are many things that can be analyzed as character, social value, psychological of the writer, the political situation, etc.

Movie is an art too. The movie was made with rolled into one the art and technology. Based on characteristic movie is a part of culture. Beside that movie is a form of entertainment that enacts a story by sound and a sequence of images giving the illusion of continuous movement. Many people like watching movie, such as children, adults, and elders.

In literary works character and characterization are important elements because they built the story. Character is a person represented in a movie, story or other narrative work. Character have particular moral, intellectual, and emotional qualities which represented from what the person say in the dialogue and from what they do the action. Every topic in movie has different influence, As the movie that the resercher want to discuss, the main characters has a psychology disorder. Psychology is the scientific study of mind and behavior. The word "psychology" comes from the Greek words "psyche," meaning life, and "Logos," meaning explanation. John Nash in this movie has a psychology disorder that is the schizophrenia.

A Beautiful Mind as the object of the discussion with title "The schizophrenia in the main character of a Beautiful Mind movie directed by Ron Howard" is very interesting and the Moral value of this movie is as a human being we do not have to surrender to achieve appreciation for the better life.

Schizophrenia in main character of A Beautiful Mind movie Directed by Ron Howard, the main character's named John Nash and the movie was released in United States on December 21, 2001.

\section{Theoretical Framework}

Nowadays, watching movie becomes one of the daily activities for many people. People may have different purpose in watching movie, such as, for refreshing, adding knowledge, studying foreign language, and understanding foreign culture.

According to Andrew Vassiliou ( 2006:2) “A film, otherwise known as a movie, moving picture, motion picture of 'Flick' is defined as: “ a sequence of photographs projected onto a screen with sufficient rapidity as to create the illusion of motion and continuity" or "a form of entertainment that enacts a story by sequence of images giving the illusion of continuous movement”. It means that film 
is a form of story or motion image continuously, so we can get the message from the motion image that we watched.

Character is an important element in literature. Various characters in the story are made by author's creativity. Author creates the characters according to their tastes: for example, the profession, status and attitudes. Every character has different part in the story.( Huntley,2007:8).Other definition proposed by Andrew Bennett and Nicholas Royle (2014:63), they said that "Character are the life of literature : they are the objects of our curiosity and fascination, affection and dislike, admiration and condemnation.

The word schizophrenia which translates roughly as "splitting of the mind" and comes from the Greek skhizen, meaning "to split" and phren, meaning "mind", schizophrenia does not imply a "split personality" or "multiple personality disorder" a condition with which it is often confused in public perception. Rather, the term means a "splitting of mental function", reflecting the presentation of the illness.

According to Levine (2009:10) "Schizophrenia is a brain disorder characterized by a variety of different symptoms, many of which can dramatically affect an individual's way of thinking and ability to function". It can be said that Schizophrenia is brain disorder which have a variety symptoms.

The next argument comes from Brain (2012:15) "Schizophrenia is a psychosis, which means that the individual does not have the grip on reality that someone suffering from a neurosis has. Symptoms of schizophrenia include hallucination, thought disorders, language disturbances and inappropriate feelings (or flattening of feelings).” It means that schizophrenia is Psychosis and the symptoms are hallucination, thought disorders, language disturbances and inappropriate feelings. There are five types of symptoms characteristic of schizophrenia namely :delusions, hallucinations, disorganized speech, disorganized behavior, and the so-called "negative" symptoms.

From all those definition, the writer can conclude that schizophrenia is brain disorder which have a variety symptoms, not only characterized by positive symptom of hallucinations, delusions, thought disorder and disorganized behavior. But also they do not socialize with the environment.

\section{RESEARCH METHOD}

The methods and some procedures are used to complete this analysis. The researcher applies descriptive qualitative research method, the researcher is using descriptive data in the form of words written or spoken of people and offenders can be observed. The researcher takes source from movie, the researcher collect the data to analyze that is The Schizophrenia in The Main Character of $A$ Beautiful Mind movie Directed by Ron Howard.

In adition, the researcher use library research for data collection method. It means tht the researcher collects several books from diferent author and takes some points that related with the topic of research to conduct and to finish this analysis.

And then the data analyzed with some procedures to makes consummates this analysis. The prcedures are first the researcher watches a beautiful movie epeteadly to understand and to get idea to choose the title. Furthermore, some theories from several books that related with the title to analize schizophrenia in main character are analyzed; second, data and information were identified from the theories. Here after, the researcher analyze the data to find the problem to discuss with deeply in this research.the last, the researcher gets the result for all of the problem and finish this research

\section{DISCUTION AND RESULT}

There are 3 types of schizophrenia found in $A$ Beautiful Mind movie. John Nash as the main character is depicted as paranoid schizophrenia, Disorganized Schizophrenia and Undifferentiated Schizophrenia. The major Symptoms characteristic of schizophrenia can be seen from the main character who suffers from the mental illness through his dialogue and scene in the movie.

\section{a. There are 3 types of schizophrenia in A Beautiful Mind movie:}

\section{Paranoid Schizophrenia}

In this movie, there are scenes that show the paranoid schizophrenia. The predominant symptoms of paranoid are hallucinations and delusions. Hallusinations

Data 1. Auditory Hallucination and Visual Hallucination.

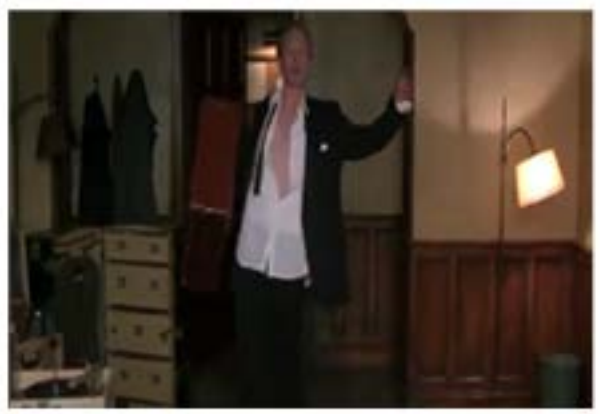

Picture 1 


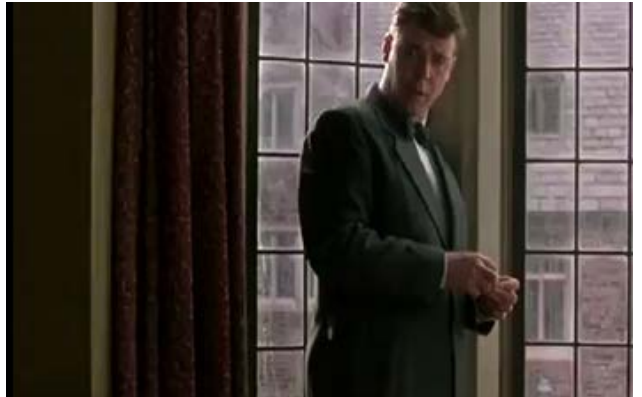

Picture 2

Nash wonder when Charles came to his room

Man : Oh, Christ. The prodigal roommate arrives.

John Nash

: Rommate?

Man

: [...] John Nash?

John Nash

: Hello.

Man

: Charles Herman. Pleased to

meet you

Nash's first hallucination is a roommate named Charles Herman, a literature student at Princeton University in 1947. While Nash looks through the window, he heard a voice of someone speaks in his room. Then he looks back, see a man enters the room and introduces himself as Nash's roommate. Nash's expression is wonder. Nash wonders when Charles comes to his dorm room by saying "roommate?" This word indicates his surprise. From the conversation above, Nash guides the viewer that he is not sure whether Charles is real or not.

Nash met William Parcher

Man : Professor Nash. William Parcher. Big Brother..at your service.

John Nash: What can I do for The Department of Defense? Are you here to give me a rise?

Another Nash's hallucination is William Parcher. He meets William Parcher, a government agent that seeks out Nash's intelligence in the field of codebreaking. While Nash goes outside after his work in MIT, someone called his name. Nash stops and looks back to a man behind him who introduced himself as William Parcher. In the movie, Parcher, as a secret agent he always wears black suit. He is the only man in the film who always wears hat that interact with Nash. Even indoors, he wears it and never put off. In American culture it is considered impolite. He does not wear his hat except in his own office. From this analysis the viewer can comprehend that William Parcher is Nash's hallucination.

a. Delusions

Nash experiences delusions of persecution, delusions of grandeur, delusions of reference, and delusions of control. Those things will be explained in detail as follows:

\section{data 2. Delusion of Persecution}

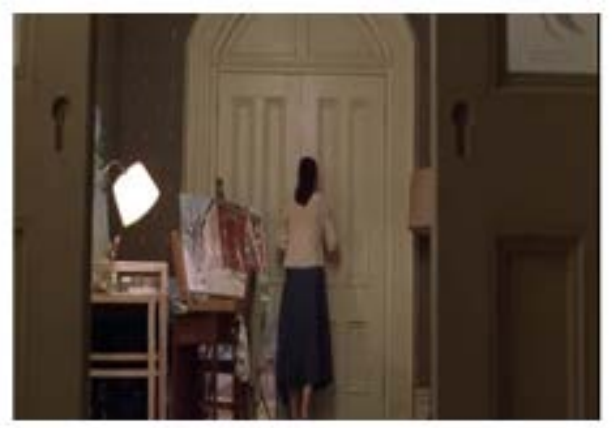

Picture 3

Alicia Wonder about Nash’s attitude

Nash has experiences the delusion of persecution in which the Russians are persecuting him. After being chased by the Russians and an exchange of gunfire, Nash become weird. He comes home late and Alicia asks him why he did not call her, but Nash just walking through Alicia to the room and locks the door. Alicia wonders and asks Nash to open the door.

The another is delusion of Nash. He was paranoid because of the light that Alicia turn on.

John Nash : Turn it off! Turn off the light! Why would you do that? Why would you turn the light on?

Alicia : What is wrong with you?

John Nash : You have to go to your sister. I left the car out the back. You take commonwealth. No side streets, you stay where it's crowded

Nash also acts so strange in his house. He becomes angry when Alicia turns the light on of his room. He also asks Alicia to go to her sister's house and not to far from the crowd, but Alicia refused. After it he is looking the window carefully, he sees Parcher out from his car.

\section{Disorganized Schizophrenia}

The main featureof disorganized schizophrenia is speech that is very disorganized, illogical, and hard to follow. The other symptom is disorganized behavior, causing impairments in person's ability to take care of him or herself, work, and interact with others.

Data 1. Disorganized Speech

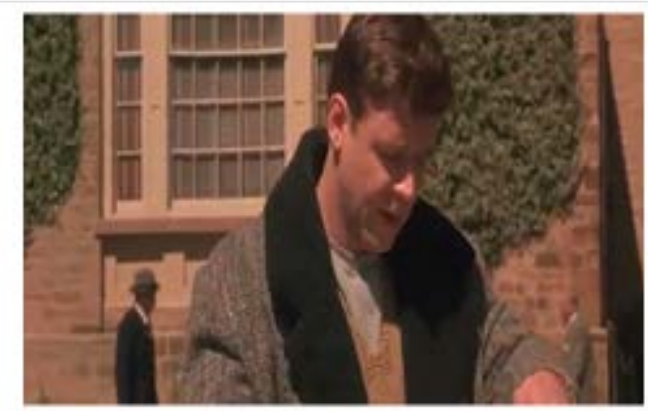

Picture 4

Nash talked something that no one unders Martin Hansen : Nash is going to stun us all with his 
genius. Which is another way of saying, he doesn't have the nerve to compete. You scared?

John Nash : Terrified, mortified, petrified, stupefied..by you. No starch. Pressed and folded. (00.09.46-00.10.04)

Disorganized speech of Nash is shown in his word when he is challenged by his friend, Hansen to play Go. He says "Terrified, mortified, petrified, stupefied by you. No starch. Pressed and folded”.

The other example is, when Nash tells Charles that he tries to find his original idea, he works out calculation oh the glass window of his dorm room and dismisses classroom instruction as " the finding of lesser mortal." He emphasizes the word of "lesser mortal” with high tone. We see people looking up when they heard Nash's shooting.

Nash said something to people loudly

John Nash : You know half these schoolboys are already published? I cannot waste time with these classes. And these books, memorizing the weaker assumptions of lesser mortals! (00.08.23 00.08.36)

Data 2 disorganized behavior

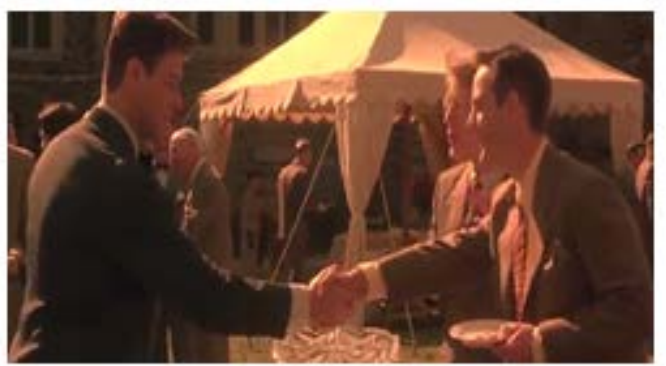

Picture 5

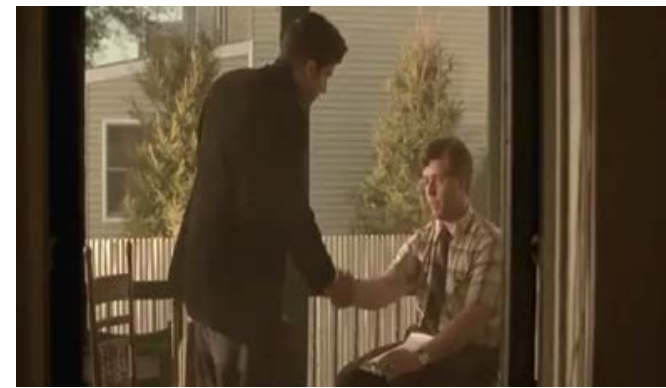

Picture 6

It can see the disorganized behavior of Nash when shaking hand to someone; he does not see people's face. From Picture. 5 and 6 above, he also does not see people's face when they are talking. From the picture above, it show that Nash shaking hand with his friend and talking to people without looking their face when he does not realize that he has one of the symptoms of schizophrenia.

He also shows his awkward gestures when he talks to someone. It is shown from Picture 1 below when he talks to Hansen that there is no innovative idea in Hansen's paper. From picture 2 below when Alicia invites Nash to go dinner. Then Picture 3 below when Nash tells Charles that he meets a girl and wants to marry her. All of these awkward gestures happen when he does not realize that he is schizophrenic.

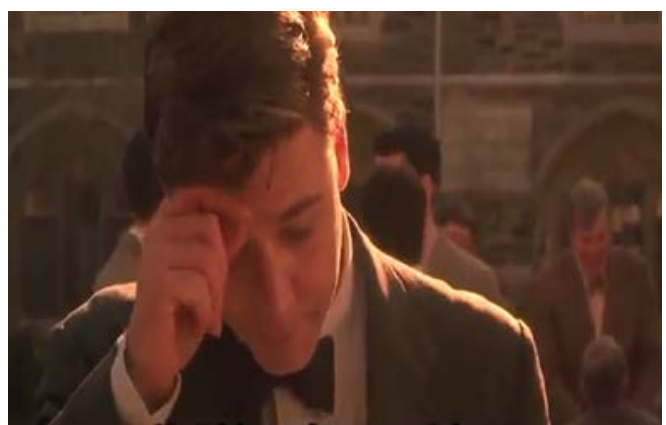

Picture 7

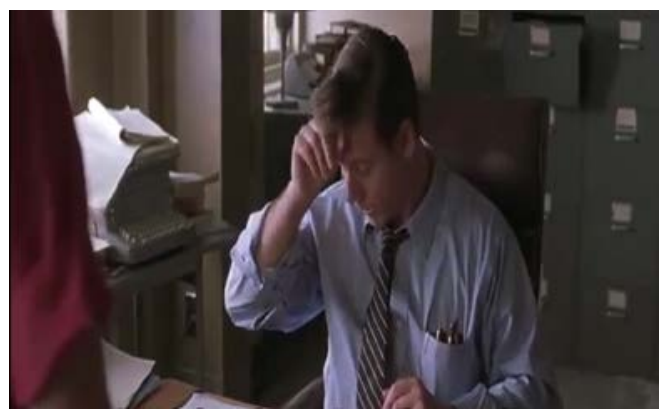

Picture 8

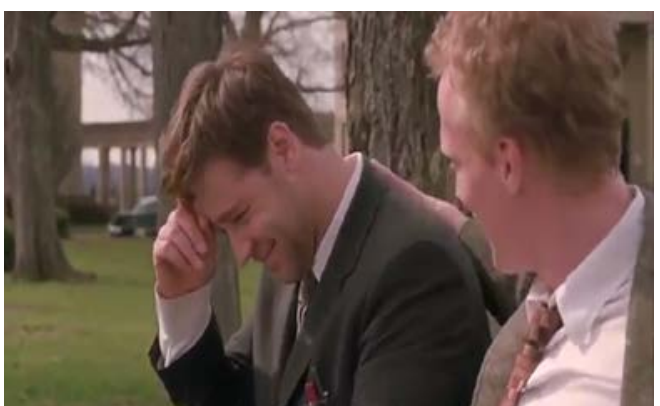

Picture 9

\section{Undifferentiated Schizophrenia}

If an individual doesn't have the characteristics of the other three types schizophrenia, it is classified as undifferentiated. It can be said that the other symptoms for undifferentiated is negative symptoms. The negative symptom in this movie is seeming lack of interest in the world: social withdrawal.

Data 3. Social withdrawal 


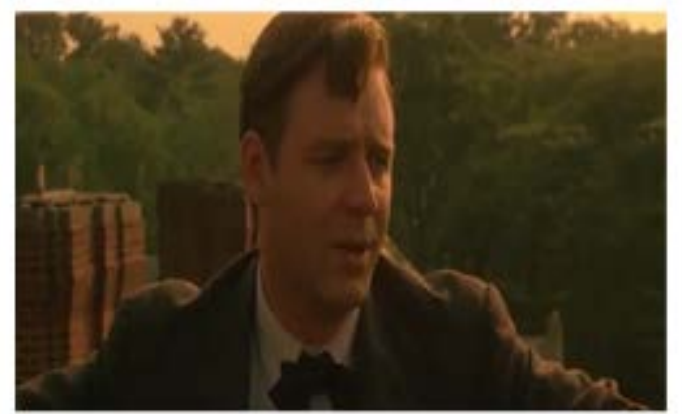

Picture 10

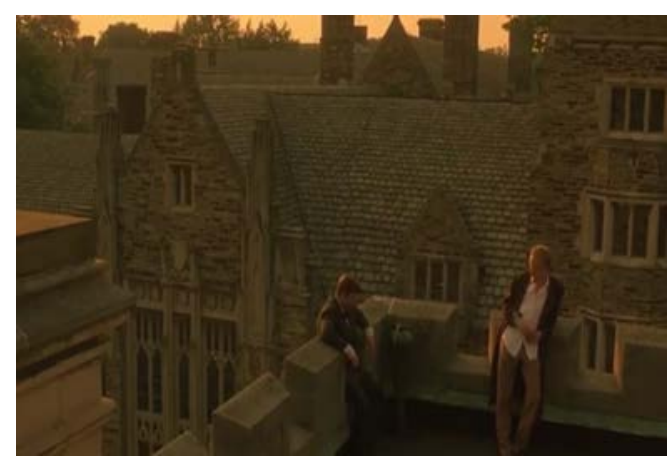

Picture 11

Based on picture 10 and 11 above Nash said that he doesn't like people.

Charles : Maybe you're just better. which the old integers than you are With people.

John Nash : My first grade teacher, she told me..that I was born with two

helping of brain, but only half a helping of heart.

Charles : Wow! She sounds lovely!

John Nash : The truth is that I-I don't like people much. And they don't like me.(00.07.43-00.08.02)

In the movie, Nash withdraws himself from people. $\mathrm{He}$ is unsociable man and rarely find himself interacting with people. When he is in university, he tells Charles that he does not like people, and they do not like them too. Nash's opinion emphasizes that he doesn't has good relationship with people is true.

\section{b. The struggle of main character}

The struggle of the main characters is showed in many scene. Nash struggles to ignore his hallucination friends and tries to socialize with people. Alicia, his wife, she always supports Nash to Struggle with his schizophrenic. Until Nash win the Nobel Prize.

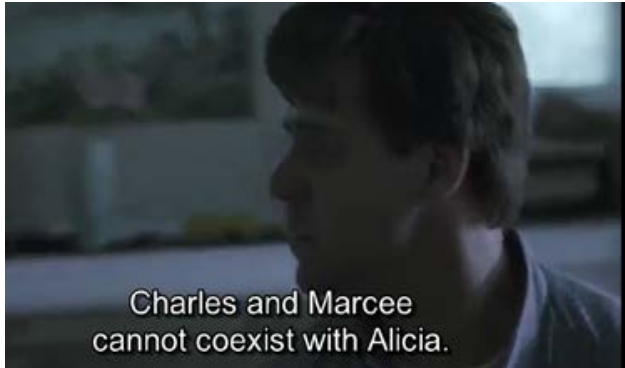

Picture 12

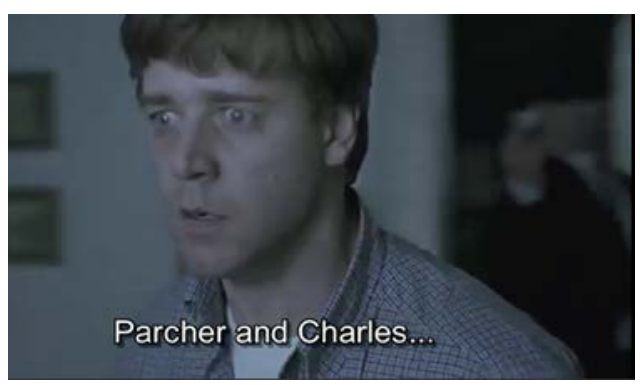

Picture 13

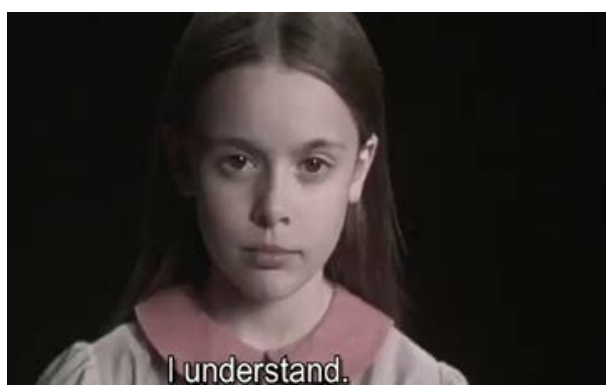

Picture 14

From Picture 12 until Picture 14 he struggles to understand that Parcher, Marcee and Charles cannot coexist with Alicia. He tries to remember all about Parcher, Marcee and Charles. It happens while bathing his son. Alicia barely manages to save their children from drowning. Then Alicia runs to the phone to call the psychiatric hospital. Parcher, Charles and Marcee appears. Parcher and Charles urge Nash to kill his wife. Nash tries to ignore. He pulls Parcher away from his wife because he tries to shoot Alicia. Then, he also understands that Marcee just his hallucination.

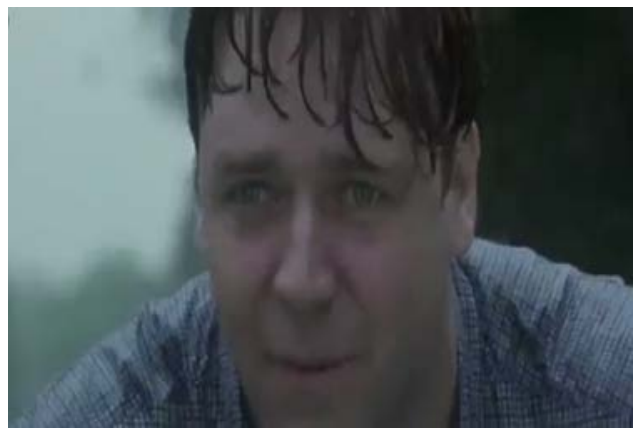

Picture 15

Nash made sure to Alice that Marcee can’t be real. 
John Nash : I understand. She never gets old. Marcee can't be real. She

never gets old. (01.38.22 - 01.38.47)

With Nash's dialogue, we know that Marcee is another Nash's hallucination like Charles and Parcher. Later, Alicia brings Dr. Rosen to say to John. Dr. Rosen says that John need to start on a higher run of insulin shocks and a new medication. But john, does not want.

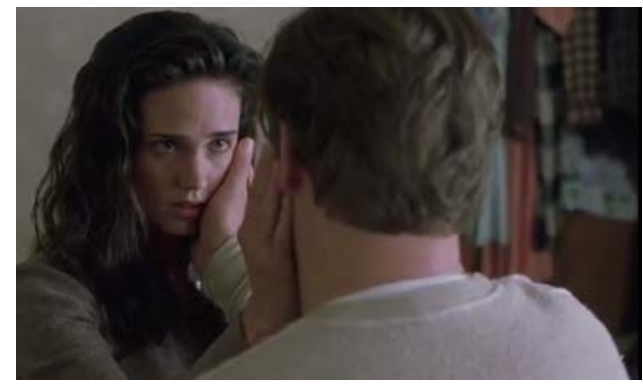

Picture 16

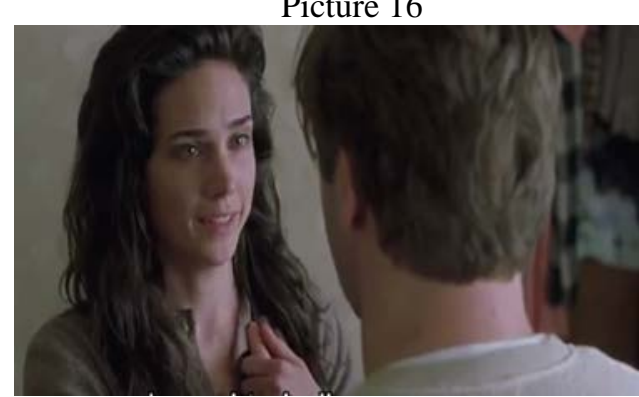

Picture 17

Nash got motivation from her wife, Alicia.

Alicia : You want to know what is real? This [while wipe Nash's

cheek and hold his hand] this is real. Maybe the part..that knows the waking from the dream.. maybe it isn't here. Maybe it's here [touch Nash's chest] . I need to believe that something extraordinary is possible

John Nash ： [Nod's head] (01.44.12 01.45.10)

After that incident, Alicia always supports Nash. She tries to make Nash sure that he can recover by saying "I need to believe that something extraordinary is possible”. With Alicia's word, Nash feels better. Two months later, he goes to the Princeton University to meet Martin, his friend.

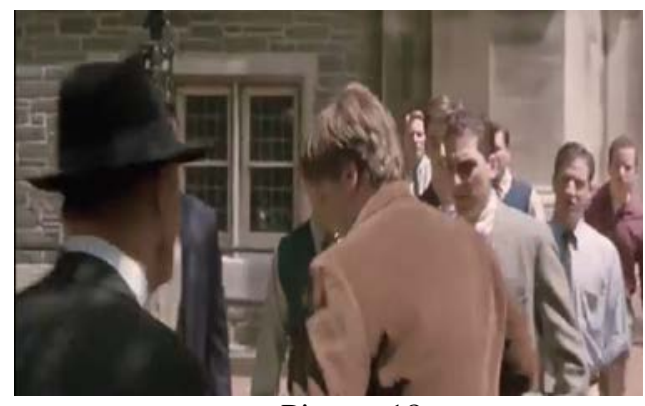

Picture 18

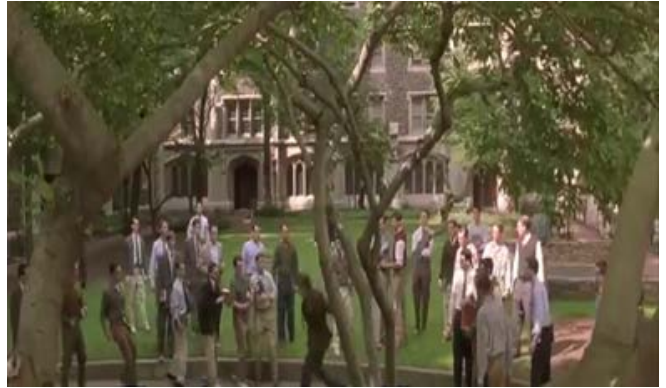

Picture 19

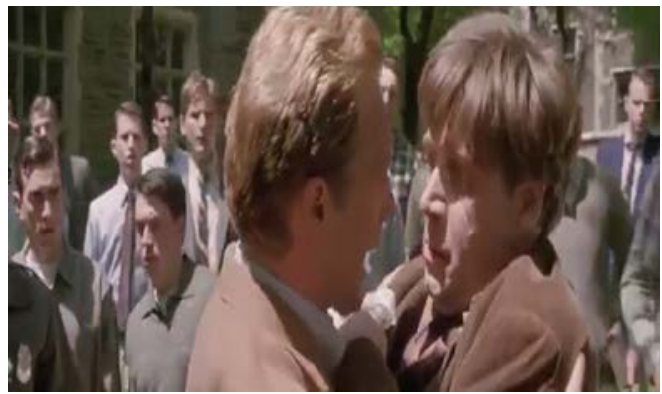

Picture 20

\section{Parcher annoyed Nash with his word}

John Nash : You're not real. You're not real! William Parche $r$ : Is that what you are, soldier? Some useless ghoul? A local madman?

John Nash : I am not a soldier.

William Parcher : you'll end up in a cell! Old, worthless, discarded.

John Nash : There is no mission,

William Parcher : While you rock and drool, the world will burn to ashes!

John Nash : You're not real. You're not real!

William Parcher : you're still talking to me, soldier. John Nash : There is no mission! I'm not a soldier!

Martin : John, John, hey, hey ,hey .John, it's okay! I just heard what happened, I'm sorry!

John Nash : I'm not a soldier.

Martin : John, hey Nash. Nash , hey you're all right. (01.49.33 - 01.50.18)

After Nash meets martin in Princeton University, Parcher appears and tries to influence Nash by saying that he is useless man. Parcher always follows Nash to make his mind disorganized. But he tries to ignore and to rebut William Parcher's word. Then, Martin comes and makes john calm. He is back to home and tells to Alicia about incident that happened in the university. John feels sad, but Alicia always give support to John by saying “ maybe try again tomorrow”.

In the first class, Charles and Marcee follow him. John tries to ignore, than Chales say something. Finally, john says not only to Charles, but also to Marcee that he will not talk to them. Day by day, his hallucination friends never lost, but he tries habitually to ignore them. Until one of the student come to him, that is the first time John take a 
conversation to other people who develop his theory that he wrote in Princeton. It makes John gets better and brings him to be a professor.

In March 1994, Nash was being considered for the Nobel Prize. From Picture III.62 in December 1994 he goes on to win the Nobel Memorial Prize. Then, From Picture III.63 and Picture III.64 "Nash's theories have influenced global trade negotiations, national labor relations, and even breakthroughs in evolutionary biology. John and Alicia live in Princeton, New Jersey. John keeps regular office hours in the Mathematics Department. He still walks to campus everyday.”

The end titles make closure interpretation that Nash improves enough to live a more normal life, even though his hallucinations and delusions never gone, but he never think about it.

\section{c. Moral Value in the movie of beautiful mind}

A Beautiful Mind movie makes someone who suffers from it are not unlike the rest of life. The movie makes us wonder. The main character, John Nash, although he was diagnoses schizophrenic he always struggle with his illness. John Nash is someone who has strong desirability to fight with himself. He tries to get up from his schizophrenia. Many troubles always come, but he always believes that he can recover from it. As a human being, sometimes trouble makes us surrender. But if we do not try to find the solution, we cannot pass it. After many troubles that we passed, of course there are beautiful things that God plans for us.

Then, we can also get the moral value from his wife, Alicia. While Nash begins to behave erratically, she never leaves him alone. Yet, she tries to observe Nash's behavior. Then, she wants help her husband to recover by inform a psychiatric hospital. Nash is hospitalized by Dr. Rosen. After she knows that Nash is schizophrenic. She always supports Nash with her patience and love until Nash gets better. Like as Nash's speech, “It is only in the mysterious equations of love that any logical reasons can be found. I am only here tonight because of you. You are the reason I am. You are all my reasons.” From Nash's speech above, he understands that with love he gets better.

\section{CONCLUSIONS}

The summary of the whole contents of the paper had been analyzed. First, is about kinds of schizophrenia in main character that experienced by John Nash. John Nash is depicted as paranoid schizophrenia, disorganized schizophrenia, and undifferentiated schizophrenia. The symptoms of paranoid are hallucination and delusion. The symptoms of disorganized schizophrenia are disorganized speech and disorganized behavior. And for the symptoms of the undifferentiated schizophrenia is seeming lack of interest in the world: social withdrawal.
Second is the struggle of John Nash. Nash struggles to ignore his hallucination friends and tries to socialize with people. He struggles to understand that Parcher, Marcee, and Charles cannot coexist with Alicia.It can be said that they are just Nash's hallucination. Nash always try to ignore Charles and Parcher's word. Alicia, his wife, always supports Nash. She tries to make Nash sure that he can recover.Until Nash experiences of better alteration and wins the Nobel Prize in Economics for his revolutionary work on game theory.

Third is about the moral value from this movie. As a human being, people may not surrender from trouble that comes in our life. If they do not try to find the solution, they can not pass it. God give us trouble just because of love. Just obedient, patient, and believe to Him. People can know the biggest miracle will come after the storm. And in this movie, the moral message comes from his wife, Alicia. She always supportNash with her patience and love without complain anything until Nash gets better. Like as Nash's speech, "It is only in the mysterious equations of love that any logical reasons can be found. I am only here tonight because of you. You are the reason I am. You are all my reasons.” From Nash's speech above, he understands that with love he gets better.

\section{REFERENCES}

Ariyasa, I Wayan Eka. 2016. The Influence of Setting on the Three Dimensional Aspects of Main Character In The ALCHEMIST. Vol. 15 number 1, April 2016. Retrieved from:http://download.portalgaruda.org/article.ph p( May 24th, 2016)

Barkin, Kay. 2016. Glossary of Mental Health/Mental Illness Terminology. US.Retrievedfrom:http://www.mentalhealthconn ection.org (May 24th, 2016)

Bennett, Andrew and Nicholas Royle. 2014. An Introduction To Literature, Critism and Theory. Britain : Pearson Education Limited.

Brain, Christine. 2012. EdexcelA2 Psychology Student Unit Guide: Unit 4 New Edition How Psychology Works. UK. Licensing Agency Ltd.

Cherry, Kendra. 2016. A List of Psychological Disorders. Retrieved from:

https://www.verywell.com/a-list-of-psychologicaldisorders-( May 18th, 2016)

Culler, Jonathan. 2009. Literary theory. New York : Sterling Publishing Co. Inc 
Eagleton, Terry. 2008. Literary Theory :An Introduction. Minneapolis: University of Minnesota Press.

Elsaesser, Thomas and Warren Buckland. 2002. Studying Contemporary American Film A Guide to Movie Analysis.

Henderson, Victoria. 2013. All American: Glossary of Literary Terms. Retrieved from: http://faculty.ksu.edu.sa/omarhuwari/Documents/ ( May 19th, 2016)

Levine, Jerome and Irene S. Levine. 2008. Schizophrenia for DUMMIES. Indianapolis, Indiana: Wiley Publishing, Inc.

Lombardi, Esther. 2015. Literature. Retrieved at: Classiclit.about.com/od/literaryterms/g/aa_whati sliter.htm

McBridge, Kelli. 2009. Introduction to Literature \& ENG/HUM 2433 World Literature I: Literary Glossary. Retrieved from: http://kellimcbride.com/litglossary.htm (may 21st, 2016)

Milhorn, H Thomas. 2006. Writing Genre Fiction: A Guide to the Craft. Florida, USA: Universal publisher .

Mulyawan, I Wayan. 2015. Three Dimensional Aspects of the Major Character in Oscar Wilde's Vera. Vol. 15 number 1, April 2015.Retreived from:

https://repository.usd.ac.id/5044/1/2471_PHENO MENA+VOL.15+NO.+1+-

+April+2015+\%2528RS\%2529.compressed.pdf (May 21st, 2016)
Plante, Amber. 2013. Voyages in Fourth Grade Language Arts: Student Edition. USA: 12 Complete Curriculum.

Smith, Meli and Jeanne Segal. 2016. Schizophrenia. Retrieved at: http://www.helpguide.org/articles/schizophrenia/ schizophrenia-signs-types-and-causes.htm (June 11th, 2016)

Vassiliou, Andrew. 2006. Analyzing Film Content: A Text-Based Approach. UK: University of Surrey.

William C. Lloyd. 2013. Psychological Disorders. Retrieved

at: https://www.healthgrades.com/right-care/mentalhealth-and-behavior/psychological-disorders. (June 4th, 2016)

\section{Biodata Penulis}

Dr. Sri Arfani, S.S, M.Pd. Memulai karier mengajar pada tahun 1998 di LPIA cikarang dan Bekasi, pada saat itu beliau dipercayakan menjadi Koordinator bidang akademik Bahasa Inggris. Pada tahun 2004 beliau bergabung menjadi dosen tetap di ABA BSI Jakarta hinggga sekarang. Beliau juga telah berpengalaman menjadi pembicara di beberapa seminar internasional dan nasional, dan telah menghasilkan beberapa karya ilmiah.Saat ini beliau telah selesai melanjutkan studi S3 di Universitas Negeri Jakarta di jurusan Pendidikan Bahasa dengan kosentrasi pendidikan bahasa Inggris. 